\title{
Bronchorrhea in Bronchioloalveolar Carcinoma
}

\author{
Konstantinos Psathakis ${ }^{a} \quad$ Klementine Bostantzoglou $^{a} \quad$ Dimitrios Sambaziotis $^{b}$ \\ Konstantinos Tsintiris ${ }^{a}$
}

Departments of a Pneumonology and ${ }^{b}$ Pathology, Army General Hospital of Athens, Athens, Greece

A 79-year-old woman, non-smoker, came to the hospital because of weight loss $(8 \mathrm{~kg}$ within the previous 2 months) and productive cough. Her previous medical history was irrelevant. The patient daily expectorated a large amount of frothy sputum; almost 2 cups of $100 \mathrm{ml}$ each (fig. 1). Auscultation of her chest revealed fine inspiratory crackles bilaterally, whereas arterial blood gas

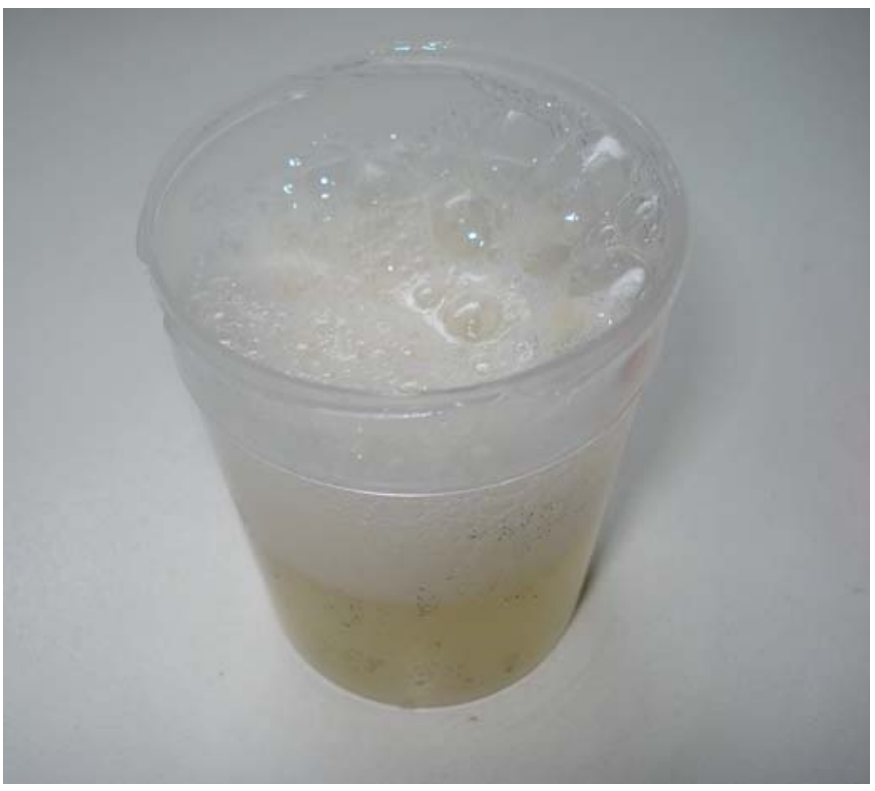

Fig. 1. Frothy sputum expectorated by the patient and collected in a cup of $100 \mathrm{ml}$.

\section{KARGER}

Fax +4161306 1234

E-Mail karger@karger.ch

www.karger.com (c) 2011 S. Karger AG, Basel

$0025-7931 / 11 / 0821-0054 \$ 38.00 / 0$

Accessible online at: www.karger.com/res measurement showed mild hypoxemia $\left(\mathrm{pO}_{2}=65 \mathrm{~mm}\right.$ $\mathrm{Hg}$ ). Radiographic examination by chest X-ray (fig. 2) and a subsequent computed tomography scan of the chest demonstrated bilateral air space and nodular opacities on all lung fields without lymphadenopathy. Transbronchial lung biopsy confirmed the diagnosis of bronchioloalveolar carcinoma (fig. 3).

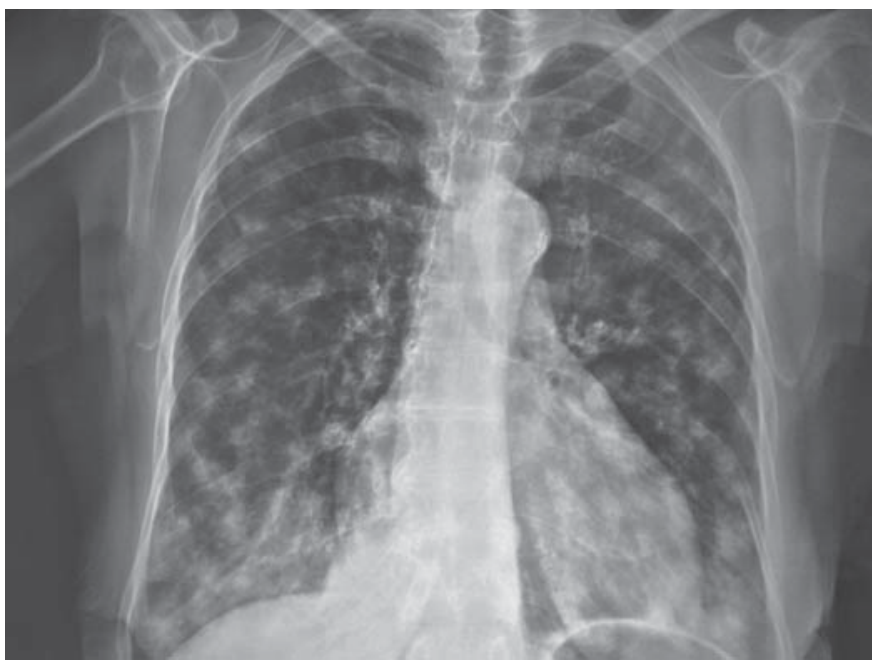

Fig. 2. Radiographic examination by chest X-ray.

Konstantinos Psathakis, MD, PhD, FCCP Terpsichoris 61

GR-17341 Athens (Greece)

Tel. +30 2107494805

E-Mail kpsazakis@hol.gr 


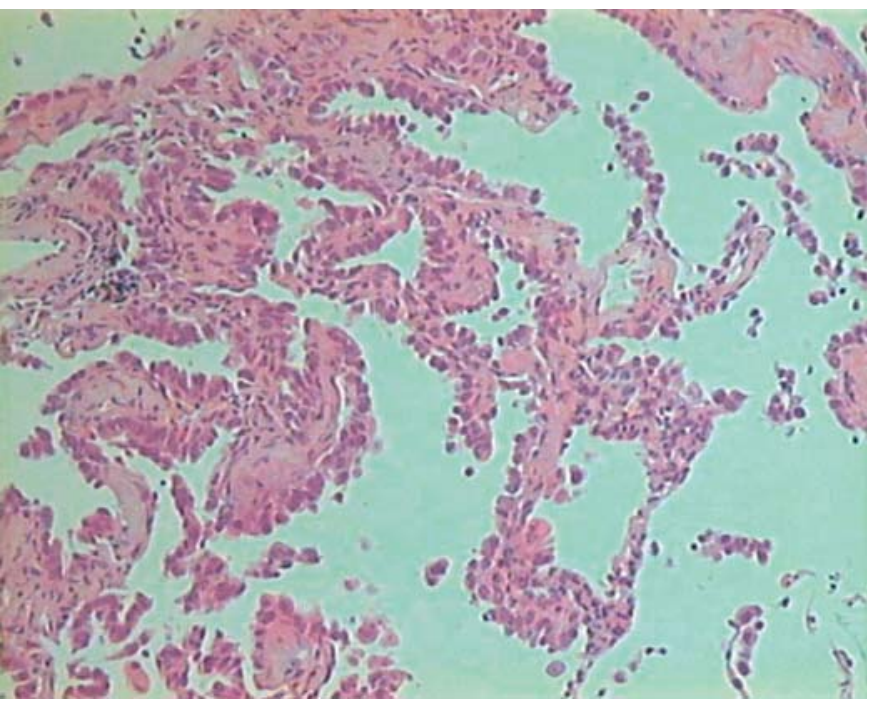

Fig. 3. Transbronchial lung biopsy (hematoxylin and eosin $\times 100$ ).

Bronchioloalveolar carcinoma is a subtype of pulmonary adenocarcinoma, developing from terminal bronchiolar or acinar epithelia and progressing along the lining of alveolar walls (a pattern referred to as 'lepidic growth') and/or by aerogenous spread, but without evidence of stromal, vascular or pleural invasion. Figure 3 shows cuboidal- and columnar-shaped neoplastic cells growing on intact alveolar walls in a lepidic fashion.

The term 'bronchorrhea' refers to the quantity of the sputum production, defined as $>100 \mathrm{ml}$ daily. Bronchorrhea along with the frothy appearance of the sputum, which indicates an origin from the distal airways, although not always present, is a unique feature of the disease [1-3].
References
1 Garfield DH, Cadranel JL, Wislez M, Franklin WA, Hirsch FR: The bronchioloalveolar carcinoma and peripheral adenocarcinoma spectrum of diseases. J Thorac Oncol 2006; 1:344-359.

-2 Raza DJ, Kima JY, Jablonsb DM: Diagnosis and treatment of bronchioloalveolar carcinoma. Curr Opin Pulm Med 2007;13:290296.

$\checkmark 3$ Pusztaszeri M, Orcurto MV, Schmidt S, Krueger T: Solitary nodular pure bronchioloalveolar carcinoma. Respiration 2010;79: 243-244. 